\title{
Changes in pastoral farming practices and pasture persistence - a review
}

\author{
D. A. CLARK \\ DairyNZ, Private Bag 3221, Hamilton \\ dave.clark@dairynz.co.nz
}

\begin{abstract}
From 1990 to 2010 there have been major changes in New Zealand pastoral agriculture. The intensification of the dairy industry has led to higher stocking rates, lower grazing residual DM, higher $\mathrm{N}$ fertiliser use and increased supplementation. However, there is little evidence that these changes are responsible for the decreased persistence of ryegrass-based pastures, rather the interactions between low summer rainfall, low water-holding capacity soils, endophyte status and cultivar 'type' have caused significant pasture damage. These factors, together with plant nutrient status (especially $\mathrm{N}$ ) and plant population survival mechanisms (tiller dormancy, birth and death rates, seed production and establishment) are hypothesised to be the primary drivers of ryegrass persistence. A secondary subset of pests, diseases, weeds and high grazing intensity (pugging and pasture 'pulling') are considered to interact with the primary drivers to compromise ryegrass tiller survival. Attention to plant species and cultivar selection, tiller replacement mechanisms and ryegrass cultivar development are required to improve ryegrass persistence.
\end{abstract}

Keywords: climate, dairy, $\mathrm{N}$ fertiliser, perennial ryegrass, white clover

\section{Introduction}

Factors affecting perennial ryegrass persistence were summarised by Kemp (2000) and included environment, plant characteristics, pests and diseases and soil and pasture management. Although single factors can influence pasture persistence, defined here as maintenance of a desired species through time without major intervention, it is more likely that several factors interact to determine the productive life of a ryegrassbased pasture, e.g. the effect of insect predation on plants with low tiller birth rates due to drought. In a review of the persistence of perennial ryegrass in sheep pastures in south-western Victoria, Waller \& Sale (2001) suggested flexible grazing management as a method to improve persistence. They suggested either allowing ryegrass to flower late in the season thereby preventing new vegetative growth and allowing tiller buds to remain dormant, or allow ryegrass seed heads to shed seed and contribute to seedling recruitment in the following autumn. A survey by Daly et al. (1999) found that sheep and beef farmers ranked pasture persistence fourth in importance after pasture quality, animal health and soil fertility in terms of importance to the whole farm system. This review concentrates mainly on factors that may affect ryegrass persistence in dairy pastures because the problem is causing much greater concern in non-irrigated dairy pastures than in either irrigated dairy pastures or intensive sheep pastures.

\section{Climate}

Farmers attribute much of the problem of persistence to climatic conditions with summer-autumn drought, wet winter-early spring and high summer temperatures being the main concerns for ryegrass and white clover survival.

\section{Summer drought}

Ryegrass and white clover both have shallow root systems, especially in compacted soils, which make them susceptible to droughts. Popay \& Crush (2010) reported $87 \%$ of perennial ryegrass roots in the top 10 $\mathrm{cm}$ of a pumice soil. Poor summer growth can lead to lower residuals and pasture pulling, and increase susceptibility to insect depredation, especially if ryegrass has low endophyte status or contains AR1 endophyte in areas where black beetle (Heteronychus arator) is present. Drought makes it difficult for daughter tillers to become established, and because these form the basis for winter and spring growth, long

Figure 1 Cumulative rainfall $(\mathrm{mm})$ January-March for 2001-2010 for Hamilton, Ruakura sites (\#12616, \#26117), the horizontal line represents mean for 1971-2000 (NIWA 2010).

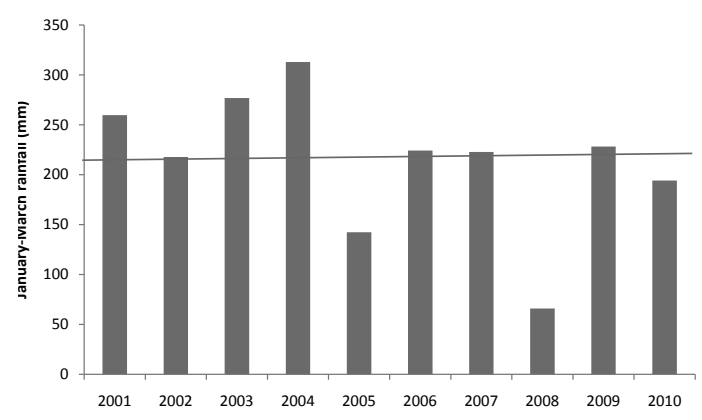


Table 1 Contribution (\%) of perennial ryegrass, white clover and dead matter to summer DM yield for pastures stocked at different rates with different inputs of nitrogen fertiliser, irrigation and purchased maize silage (mean of 5 years - 20012005; standard deviation in brackets) (unpublished data from Resource Efficient Dairy experiment, Newstead, Waikato).

\begin{tabular}{|c|c|c|c|c|c|c|}
\hline Treatments & $A$ & $\mathrm{~B}^{*}$ & $\mathrm{C}$ & $\mathrm{D}$ & $E$ & $\mathrm{~F}$ \\
\hline Ryegrass & $61.3(7.9)$ & $61.9(9.1)$ & $54.0(6.2)$ & $67.2(8.8)$ & $58.7(6.5)$ & $62.9(7.8)$ \\
\hline White clover & $14.6(5.4)$ & $13.2(6.9)$ & 21.3(10.2) & $11.1(7.2)$ & $21.1(10.1)$ & $19.5(9.1)$ \\
\hline Dead matter & $10.7(4.9)$ & $12.1(8.2)$ & $9.9(3.7)$ & $8.7(4.3)$ & $8.0(4.3)$ & $5.8(1.3)$ \\
\hline $\begin{array}{l}\text { Stocking } \\
\text { (cows/ha) }\end{array}$ & 3.0 & 3.0 & 2.3 & 3.8 & 5.3 & 7.0 \\
\hline $\mathrm{N}$ fertiliser $(\mathrm{kg} / \mathrm{ha} / \mathrm{yr})$ & 200 & 200 & 0 & 200 & 200 & 200 \\
\hline $\begin{array}{r}\text { Maize silage } \\
\text { (t DM/ha/yr) }\end{array}$ & 0 & 0 & 0 & 5 & 10 & 20 \\
\hline Irrigation & - & - & - & - & Yes & Yes \\
\hline
\end{tabular}

${ }^{*} \mathrm{~B}$ - as for treatment $\mathrm{C}$ but with use of standoff pad in winter-spring.

term effects are possible; gaps will allow weeds (e.g. Poa spp.) to become established in autumn. In the past 6 years much of the northern North Island has been affected by summer-autumn drought with especially serious drought in 2005 and 2008 in the Waikato (Fig. 1). Despite increased supplements and drought management strategies such as early culling and once-daily milking, many pastures have been grazed below recommended residuals with obvious effects on 'pasture pulling', weed ingress and slow recovery in the subsequent year.

\section{Winter - early spring rainfall}

Ryegrass can be damaged by excess pugging in winter, with reduced tiller density leading to gaps allowing invasion by summer-active weeds and grasses. The natural disintegration of white clover stolons in midspring can be hastened by pugging with loss exacerbated by stolon burial. Serious pugging in September can have long term effects on ryegrass and white clover annual DM yield, with reductions of 37 and 52\%, respectively (Menneer et al. 2005); the effect on white clover was more from direct damage and burial of stolons than from soil physical property changes. Severe pugging

Figure 2 Cumulative rainfall $(\mathrm{mm})$ for July-September 2001-2010 for Hamilton, Ruakura sites (\#12616, \#26117), the horizontal line represents mean for 1971-2000 (NIWA 2010).

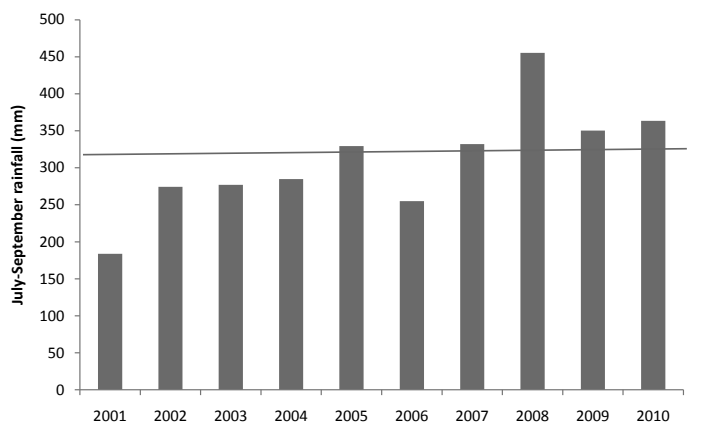

also led to three times the proportion of summer active $\mathrm{C}_{4}$ species such as summer grass (Digitaria sanguinalis) and smooth witchgrass (Panicum dichotomiflorum) compared with non-pugged control $112 \mathrm{~d}$ after pugging (Menneer et al. 2005). In the past 6 years the northern North Island has had average July-September rainfall with the exception of very high rainfall in 2008 in the Waikato (Fig. 2). Anecdotal observations suggest that this heavy rainfall after a one-in-a-100-year drought led to further damage to pastures struggling to re-establish after drought.

\section{Summer temperature}

Ryegrass has a temperature for optimum growth of $18^{\circ} \mathrm{C}$ (Mitchell, 1956), so higher summer temperatures could reduce ryegrass summer growth and also lead to increased germination and growth of $\mathrm{C}_{4}$ weed grasses such as smooth witchgrass and summer grass (Wardle et al. 1994), especially where gaps leave space for germination. In the past 6 years the northern North Island has had average or above average January-March daily maximum air temperatures with temperatures $2-3^{\circ} \mathrm{C}$ above average in the Waikato in the 2008 drought (Fig. 3). Such temperatures are not lethal

Figure 3 Mean daily maximum air temperature $\left({ }^{\circ} \mathrm{C}\right)$ for January-March 2001-2010 for Hamilton, Ruakura sites (\#12616, \#26117), the horizontal line represents mean for 1971-2000 (NIWA 2010).

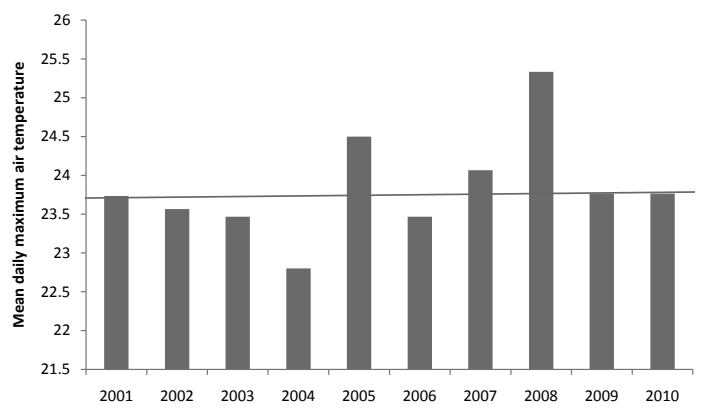


for ryegrass, but when combined with drought, overgrazing, low moisture retentive soils and black beetle damage undoubtedly compromise ryegrass and white clover survival and future production.

\section{Farm system changes Stocking rate}

Stocking rates have increased nation-wide from 2.4 to $2.85 \mathrm{cows} / \mathrm{ha}(+18.7 \%)$ from 1990 to 2008 , but in the northern regions of Northland, Bay of Plenty and Waikato stocking rates have only increased by $8.8 \%$ the national change presumably greater because of the higher stocking rates on farm conversions in the rapidly expanding South Island sector (Livestock Improvement 1990; Livestock Improvement and DairyNZ 2009). The Waikato region has the highest stocking rate for non-irrigated regions of 3.02 cows per ha. Milksolids per cow has increased by $22 \%$ from 1991 to 2009 but milksolids per ha has increased by $48 \%$ over the same period showing the importance of increased stocking rate (Fig. 4). Increased stocking rates can lead to many changes in soil and plant properties (Drewry et al. 2008) including increased bulk density, reduced macroporosity, changed soil fauna, decreased $\mathrm{N}$ fixation, soil surface disturbance leading to tiller and stolon death, and plant burial with long-term effects on DM yield and subsequent weed invasion. Increased stocking rate increases the number of urine and dung patches with both increased and decreased DM yield and changes in pasture composition dependent on nutrient concentrations.

Despite the many changes that occur with increased stocking rate, there is little evidence that stocking rate per se from 2.3 to 7 cows per ha is responsible for lack of perennial ryegrass or white clover persistence (Clark, unpublished data, Resource Efficient Dairy experiment, Table 1). Very high stocking rates did not reduce the ryegrass contribution to summer or total annual yield (data not presented) compared with lower stocking rates. But a likely reason for this result is that inputs

Figure 4 New Zealand average annual milksolids yield per cow and per ha from 1990-91 to 2009-10 (Livestock Improvement and DairyNZ 2009).

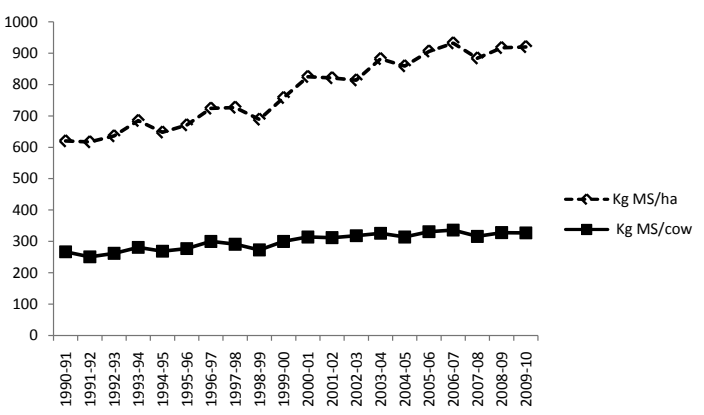

of nitrogen, maize silage and water were used to ensure that comparative stocking rates were similar on all treatments which ensured the target grazing residuals could be maintained throughout the year.

\section{Pasture management}

Some have questioned the current grazing recommendation to leave a residual of $1500 \mathrm{~kg} \mathrm{DM} /$ ha at each grazing because of their concerns for effects on ryegrass survival. This recommendation has been demonstrated over many years by the Lincoln University Demonstration Farm albeit with optimum water and nutrient inputs; although major pasture renovation has not been necessary it is not possible to conclude that such residuals have no effect on ryegrass persistence. When followed throughout the year there will be little opportunity for natural reseeding because most stems will be grazed before seed set. Under hard spring grazing (1500 kg DM/ha residual), L'Huillier \& Aislabie (1988) reported that only $5 \%$ of reproductive tillers flowered, but where laxer grazing or partial closure permitted seed set, $55-80 \%$ of tillers flowered and autumn seedling densities were $2000-4000$ per $\mathrm{m}^{2}$ and herbage DM yield was $20 \%$ higher in late summerearly winter than on spring hard-grazed plots. L'Huillier \& Aislabie (1988) suggested lax grazing (residual of $2500 \mathrm{~kg} \mathrm{DM} / \mathrm{ha}$ ) or partial reseeding in early summer could be used on $10-15 \%$ of a farm each year to renovate pastures, with the reseeded area used as a 'summer crop'. The authors stated that "In ryegrass/white clover dairy pastures reliance on vegetative propagation appears to be inadequate to maintain sward stability.... Currently, the ryegrass plant losses are replaced by the regular and increasing practice of pasture renovation by direct drilling." L'Huillier \& Aislabie (1988). This indicates that ryegrass persistence in Waikato dairy pastures was a problem with 'old' cultivars 23 years ago.

Another consequence of maintaining lower pasture residuals throughout the year may be the incursion of new $\mathrm{C}_{4}$ grass weeds, e.g., yellow bristle grass (Setaria pumila) (James et al. 2009). They identify other possible causes for progression from mere presence to serious weed in the last decade such as increased cropping, reduced roadside weed control and more establishment sites due to poor ryegrass persistence.

\section{Pasture conservation and topping}

Increased pasture utilisation has meant that opportunities to conserve surplus feed have decreased. The recognition that late, high yielding pasture silage crops often have very low metabolisable energy (ME) content has led to the practice of taking early silage crops of high quality with little seed content. Much less hay is made so these sources of seed are much 
reduced on many dairy farms. The value of high ME leafy pasture for high milksolids yield is now well accepted and topping, often before grazing, is practised, especially in late spring- summer to avoid 'clumpiness' and seed head formation. This practice will reduce seed input from a ryegrass tiller population that has survived local environment and management (L'Huillier \& Aislabie 1988).

\section{Pasture establishment and cultivar use}

These topics are dealt with in more detail by Thom et al. (2011), but briefly, there have been changes in both cultivation and direct drilling technology in the past 20 years. Cultivation used to be plough - several disc passes - roll whereas now it is more likely to be plough - power harrow - roll before sowing. After cropping, or from run-out pastures, herbicides are used to kill existing vegetation and then new pasture seeds are direct-drilled. Some problems remain the same, namely, excessive ryegrass seed rates and sowing white clover seeds deeper than $13 \mathrm{~mm}$ (Armstrong et al. 2002).

Major progress has been made in cultivar availability and selection for specific sites. But the recent debate on the merits of cultivars containing either AR1 or AR37 endophyte provides ample evidence that cultivar selection for a particular site is a complex decision with risks attached to any decision. The use of novel endophyte pastures has led to recommendations that a seedbed is prepared that is free of resident ryegrass. This allows a sward of $100 \%$ sown ryegrass to be established thus maximising novel endophyte benefits, but it also introduces the risk that there are no resident ryegrass seeds to 'fill the gaps' if there is a partial failure of the sown ryegrass. The 'modern' sown ryegrass is blamed for poor persistence but the problem could have existed in the past, but without being recognised. However, Edwards et al. (1993) found that sheep grazing either nil endophyte or endophyte-infected Nui ryegrass grazed the former much harder leaving pasture residuals of 1000 and $1260 \mathrm{~kg}$ DM per ha respectively. It is likely that recent cultivars infected with novel endophytes are more palatable to cows and sheep than ryegrass containing 'wild' endophyte, resulting in lower grazing residuals where strict management is not practised.

\section{Supplementary feeding}

Maize grown for silage for the dairy industry has increased from 3000 ha in 1994 to 72000 ha in 2008 (Booker, 2009) and latterly palm kernel expeller use (Fig. 5, Statistics New Zealand, 2009) has increased from zero in 2000 to $1.4 \mathrm{~m}$ tonnes in 2010 . These imports have supported both higher stocking rates, longer lactations, higher per cow production; in addition, they have increased nutrient loading on farms that use them. Only rarely do supplements lead to zero substitution rates (Clark \& Woodward 2007) which implies that they have a 'pasture sparing' effect which may lead to either less overgrazing or higher pasture residuals. It is unlikely that either stocking rate or supplement use per $s e$ leads to reduced ryegrass persistence (see Table 1).

The practice of grazing off all non-milking replacements and cows especially in the South Island means that quite high pre-grazing DM yields can occur in early spring on some farms. This practice, especially when combined with high $\mathrm{N}$ fertiliser use, will reduce tiller density and white clover growing points. Clark et al. (1994) found that winter spelling compared with several winter grazing regimes reduced perennial ryegrass density from 4980 to 2740 tillers/ $\mathrm{m}^{2}$ by August; white clover growing point density was also reduced, however these differences were no longer significant by November.

\section{Fertiliser}

Annual urea fertiliser use has increased from $18600 \mathrm{t}$ in 1990 to $433300 \mathrm{t}$ in 2007 (MAF, 2007) with much of this increase applied to dairy pastures. The effect of $\mathrm{N}$ fertiliser input on the performance of grazed ryegrass white clover swards is complex. In most circumstances total DM yield will increase with increased ryegrass DM response greater than any decreases in white clover yield. But the decrease of the latter is dependent on many factors, especially grazing management, and Harris \& Clark (1996) have shown white clover can be maintained at $200 \mathrm{~kg} \mathrm{~N} / \mathrm{ha} / \mathrm{yr}$. Where increased $\mathrm{N}$ fertiliser leads to increased stocking rate there is likely to be an increased area affected by urine. Marriott et al. (1987) showed a direct negative effect of urine on white clover population density, stolon length and dry weight with both a direct effect on $\mathrm{N}$ fixation and a later indirect effect due to lower clover presence. Increased $\mathrm{N}$ fertiliser can lead to decreased tiller birth rates if pasture cover increases because of basal shading

Figure 5 Annual imports of Palm Kernel Expeller (PKE) from 2001 to 2010, estimate only for 2010 (Statistics New Zealand 2009).

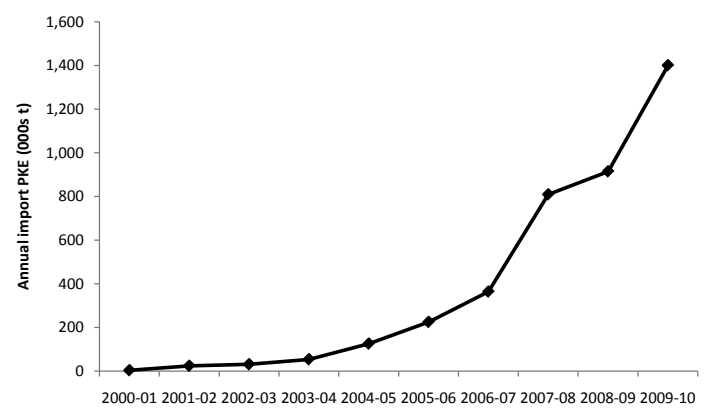


(Langer 1972), but increased tiller survival if used to establish daughter tillers in early summer (Bahmani et al. 2001). Harris et al. (1996) showed that ryegrass tiller density in establishing swards increased as applied $\mathrm{N}$ increased up to $400 \mathrm{~kg} / \mathrm{ha} / \mathrm{yr}$, implying that net tiller increment was enhanced by $\mathrm{N}$ fertiliser. Timing of $\mathrm{N}$ fertilisation, however, may be important. Bahmani et al. (2001) used Ellett ryegrass as a representative example of the Mangere ecotype (e.g. Ellett, Bronsyn, Yatsyn 1, Grasslands Nui, Vedette and Dobson) to study tiller replacement rates under different fertiliser and irrigation regimes. They found that Ellett tiller density increases at a much lower rate than Ruanui when $\mathrm{N}$ fertiliser is applied, but Ellett produces more reproductive tillers than Ruanui which means that a larger number of daughter tillers must be established in summer on the former if equivalent tiller densities are to be maintained.

There is no indication that ryegrass persistence on dairy farms will be compromised by low Olsen P levels with a high percentage of farms close to, or above, that required for maximum DM yield. But some caution is required because Carran \& Theobald (1998) analysed the long term ( 25 years) effect of intensive grazing with and without excreta return in a bull beef system and found that although soil test values were raised by excreta, variability was greatly increased. Further, the large amount of $\mathrm{K}$ cycling through excreta caused lower $\mathrm{Ca}$ and $\mathrm{Mg}$ soil contents and greater leaching losses. It is possible that intra-paddock variability in nutrient levels may be influencing ryegrass persistence by creating patches of low nutrient content that will favour the ingress of other grasses e.g. Agrostis spp (Mouat \& Walker 1959).

However, 33-50\% of samples from sheep/beef farms had Olsen $\mathrm{P}$ values below the estimated economic values for average production (Environment Waikato, 2004) implying that $P$ may be a limiting factor in ryegrass yield and persistence. This is supported by Daly et al. (1999) in a survey of sheep/beef farms where greater persistence was associated with an average Olsen P of 21.

\section{Conclusions and Implications}

This brief review of farm management changes that might have impacted on pasture persistence led to the conclusion that there is a primary $\left(1^{\circ}\right)$ subset of factors that entrain a progressive decline in ryegrass and white clover density; and a secondary $\left(2^{\circ}\right)$ subset that are broadly consequent on the initial damage caused by primary drivers. The primary subset is hypothesised to include: soil type (water holding capacity and texture), summer rainfall (total and distribution), plant nutrient status (especially $\mathrm{N}$ ) and plant population survival mechanisms (tiller dormancy, birth and death rates, seed production and establishment, endophyte status). These factors and, critically, their interactions, are responsible for the persistence characteristics of New Zealand ryegrass-based pastures. The secondary subset includes: pests (e.g. black beetle, Argentine stem weevil (Listronotus bonariensis), clover root weevil (Sitona lepidus) and root feeding nematodes (Meloidogyne spp. and Heterodera sp.), diseases (e.g. crown rust and clover viruses), weeds (Poa annua, Digitaria sanguinalis, Ranunculus spp., Cirsium spp.), high grazing intensity (pugging and pasture 'pulling'). These $2^{\circ}$ factors will rarely initiate a decline as a single factor but can interact with other $1^{\circ}$ and $2^{\circ}$ factors to lead to catastrophic losses of plants in weakened pastures. For example, upper North Island ryegrass pastures have suffered major losses in tiller density in the past 3 years but the worst losses have occurred where AR1 endophyte ryegrasses on free draining light ash or peat soils have been exposed to low summer rainfall with intermittent showers breaking tiller bud dormancy leading to tiller death. Black beetle larvae feed on roots and the adults on tillers, from December-March and high grazing pressure leads to serious pasture pulling; without renovation, pasture gaps will provide sites for Poa spp. and broadleaf weeds to invade and spring grazing management will have led to low or zero ryegrass seed input.

There is little evidence that higher stocking rates, grazing management designed to maintain high pasture quality and utilisation, increased $\mathrm{N}$ fertiliser application or purchased supplements are responsible for decreased persistence of ryegrass-based pastures. However, the interaction between low summer rainfall, low water holding capacity soils, endophyte status and cultivar 'type' have caused significant pasture damage. Assuming irrigation is not available, the following actions are required to protect the pasture feed source:

Correct plant species and cultivar selection on vulnerable soils - alternatives species such as tall fescue containing MaxP endophyte should be considered where ryegrass has failed on several occasions. Where low water holding capacity soils, occasional summer drought and insect predation coincide, then ryegrass with AR37 endophyte should be sown; and greater diversity achieved by sowing plaintain or chicory to give alternative, high quality feed sources should ryegrass production decline for any reason. In more extreme conditions Phalaris may have a place because dormancy during drought increases survival.

Tiller replacement - $\mathrm{N}$ fertiliser should be specifically used in early summer (25-40 $\mathrm{kg} \mathrm{N} / \mathrm{ha})$ to ensure the establishment of daughter tillers from existing reproductive tillers. Grazing management immediately 
after autumn rains should be aimed at establishing new tillers by avoiding grazing as much of the farm as possible for a 2-week period, based on the observation that summer-autumn tiller establishment is better under infrequent grazing (McKenzie, 1997). Winter pasture management should avoid high pasture covers that lead to basal shading and hence tiller death.

Ryegrass cultivar development - should specifically enhance tiller bud dormancy in drought conditions.

\section{ACKNOWLEDGMENT}

To Errol Thom (DairyNZ) for helpful discussion and suggestions during manuscript preparation.

\section{REFERENCES}

Armstrong, M.L.; Harrington, K.C.; Seefeldt, S.S. 2002. Weed establishment in the second year after high pasture sowing rates. Proceedings of the New Zealand Plant Protection Conference 55: 116-120.

Bahmani, I.; Thom, E.R.; Matthew, C.; Lemaire, G. 2001. Productivity of grazed perennial ryegrass pastures from different ecotypes under nitrogen and irrigation treatments. New Zealand Journal of Agricultural Research 44: 123-133.

Booker, J.W. 2009. Production, distribution and utilisation of maize in New Zealand. M. Appl. Sci. dissertation, Lincoln University, 69 pp.

Carran, R.A.; Theobald, P.W. 1998. Long-term effects of grazing on the fertility of soils. Proceedings of the New Zealand Grassland Association 60: 75-78.

Clark, D.A.; Carter, W.; Walsh, B.; Clarkson, F.H.; Waugh, C.D. 1994. Effect of winter pasture grazing residuals and grazing off on subsequent milk production and pasture performance. Proceedings of the New Zealand Grassland Association 56: 55-60.

Clark, D.A.; Woodward, S.L. 2007. Supplementation of dairy cows, beef cattle and sheep grazing pasture. pp. 117-132. In: Pasture and supplements for grazing animals. Eds. Rattray, P.V.; Brookes, I.M.; Nicol, A.M. New Zealand Society of Animal Production. Occasional Publication No. 14.

Daly, M.J.; Fraser, T.; Perkins, A.; Moffat, C.M. 1999. Farmer perceptions of reasons for perennial pasture persistence and the relationship of these with management practice, species composition, and soil fertility. Proceedings of the New Zealand Grassland Association 61: 9-15.

Drewry, J.J.; Cameron, K.C.; Buchan, G.D. 2008. Pasture yield and soil physical property responses to soil compaction from treading and grazing - a review. Australian Journal of Soil Research 46: 237 256.

Edwards, G.R.; Lucas, R.J.; Johnson, M.R. 1993. Grazing preference for pasture species by sheep is affected by endophyte and nitrogen fertility. Proceedings of the New Zealand Grassland Association 55: 137-141.

Environment Waikato. 2004. Trends in Olsen P test over time for the Waikato region. Environment Waikato technical report 2004/09, prepared by D.M. Wheeler, AgResearch. (Accessed 3 December 2010). http://www.ew.govt.nz/PageFiles/2716/TR04-09. pdf.

Harris, S.L.; Clark, D.A. 1996. Effect of high rates of nitrogen fertiliser on white clover growth, morphology and nitrogen fixation in grazed dairy pasture in northern New Zealand. New Zealand Journal of Agricultural Research 39: 149-158.

Harris, S.L.; Thom, E.R.; Clark, D.A. 1996. Effect of high rates of nitrogen fertiliser on perennial ryegrass growth and morphology in grazed dairy pasture in northern New Zealand. New Zealand Journal of Agricultural Research 39: 159-169.

James, T.K.; Tozer, K.N.; Rahman, A. 2009. Yellow bristle grass: a recent weed incursion in Waikato dairy pastures. Proceedings of the New Zealand Grassland Association 71: 39-42.

Kemp, P.D. 2000. Persistence of ryegrass pastures. Dairyfarming Annual 52: 157-162.

Langer, R.H.M. 1972. How grasses grow. Edward Arnold, London.

Livestock Improvement 1990. Dairy Statistics 1990/9.

Livestock Improvement and DairyNZ. 2009. New Zealand Dairy Statistics 2008-2009.

L'Huillier, P.J.; Aislabie, D.W. 1988. Natural reseeding in perennial ryegrass/white clover dairy pastures. Proceedings of the New Zealand Grassland Association 49: 111-115.

MAF 2007. Fertiliser statistics database. Accessed 3 December 2010. http://www.maf.govt.nz/statistics/ fertiliser/.

Marriott, C.A.; Smith, M.A.; Baird, M.A. 1987. The effect of sheep urine on clover performance in a grazed upland sward. Journal of Agricultural Science 109: 177-185.

McKenzie, F.R. 1997. Influence of grazing frequency and intensity on the density and persistence of Lolium perenne tillers under subtropical conditions. Tropical Grasslands 31: 219-226.

Menneer, J.C.; Ledgard, S.F.; McLay, C.D.A.; Silvester, W.B. 2005. The effects of treading by dairy cows during wet soil conditions on white clover productivity, growth and morphology in a white clover-perennial ryegrass pasture. Grass and Forage Science 60: 46-58.

Mitchell, K.J. 1956. Growth of pasture species under controlled environment. 1. Growth at various levels of constant temperature. New Zealand Journal of 
Science and Technology A38: 203-216.

Mouat, M.C.H.; Walker, T.W. 1959. Competition for nutrients between grasses and white clover. 1. Effect of grass species and nitrogen supply. Plant and Soil 11:30-40.

NIWA 2010: Cliflo climate database. Accessed 3 December 2010. http://www.cliflo.niwa.co.nz/.

Popay, A.J.; Crush, J.R. 2010. Influence of different forage grasses on nitrate capture and leaching loss from a pumice soil. Grass and Forage Science 65: 28-37.

Statistics New Zealand 2009. (Accessed 3 December 2010). http://www.stats.govt.nz/browse_for_stats/ industry_sectors/imports_and_exports.aspx
Thom, E.R.; Fraser, T.J.; Hume, D.E. 2011. Sowing methods for successful pasture establishment - a review. Pasture persistence. Grassland Research and Practice Series 15: 31-37.

Wardle, D.A.; Barker, G.M.; Nicholson, K.S.; Addison, P.J. 1994. Cyclic oscillations between a summerannual (C-4) and a winter-annual weed grass in Waikato dairy pastures. Proceedings of the New Zealand Plant Protection Conference 47: 34-37. 
